\title{
Anastomotic leak after primary repair of tracheoesophageal fistula: a dreadful condition
}

\author{
Deepak Sharma, Srinivas Murki, Tejo Pratap
}

Department of Neonatology, Fernandez Hospital, Hyderabad, Andhra Pradesh, India

\section{Correspondence to}

Dr Deepak Sharma, dr.deepak.rohtak@gmail.com

Accepted 13 June 2014

\section{DESCRIPTION \\ Case}

A term baby boy born with a birth weight of $2.5 \mathrm{~kg}$, with Apgar scores of 8/8/9 was admitted in our neonatal intensive care unit as a case of tracheoesophageal fistula type C. He was evaluated for any VACTERL (Vertebral defects, imperforate Anus, Cardiac defects, TEF with esophageal atresia, Renal dysplasia or defects and Limb anomalies) associated malformations, which were absent. The baby was operated on day 1 with a primary end-to-end anastomosis and was given postoperative respiratory support in the form of ventilation. At the age of day 3 , he had increase in respiratory distress with simultaneous increase in ventilation requirements. Evaluation of the baby's chest X-ray showed rightsided pneumothorax. The baby was managed conservatively with intercostal drainage tube repositioning with needle aspiration. The baby was evaluated with routine esophagram on seventh postoperative day, which showed an anastomotic leak (figures $1 \mathrm{~A}$ and $1 \mathrm{~B})$. The baby was reoperated in view of persistent pneumothorax, ventilator dependency. During the second surgery gastrostomy with oesophagostomy was performed. The baby was extubated successfully and discharged with gastrostomy tube in situ. He is now healthy with a regular following up.

\section{DISCUSSION}

The neonate is suspected as a case of TEF where there is excessive frothing from the mouth, feeding intolerance or difficulty in breathing since birth. Patients with TEF are initially screened for associated malformations including VACTERL associations. Management starts with proper positioning with head end elevation to $45^{\circ}$ to prevent aspiration, regular suctioning of secretions (replogle suction catheter). Surgical treatment of TEF includes a single-layer primary end-to-end anastomosis depending on the distance between the ends and during suturing care is taken to minimise the tension between the two ends. ${ }^{1}$ Postoperatively the patient is kept nil by mouth with total parenteral nutrition (TPN) is given to the patients and minimal feedings are started through tube feeding on 2-3 days after the operation in most cases. The patient is evaluated with esophagram on postoperative day 7 to see any anastomotic leak which is usually seen in around $15 \%$ cases. $^{2}$ In the presence of leak feeding is withheld and the patient continued on TPN, broad-spectrum antibiotics and the majority of the times the leak gets spontaneously closed without a second operation. ${ }^{3}$
To cite: Sharma D, Murki S, Pratap T. BMJ Case Rep Published online: [please include Day Month Year] doi:10.1136/bcr-2014203982
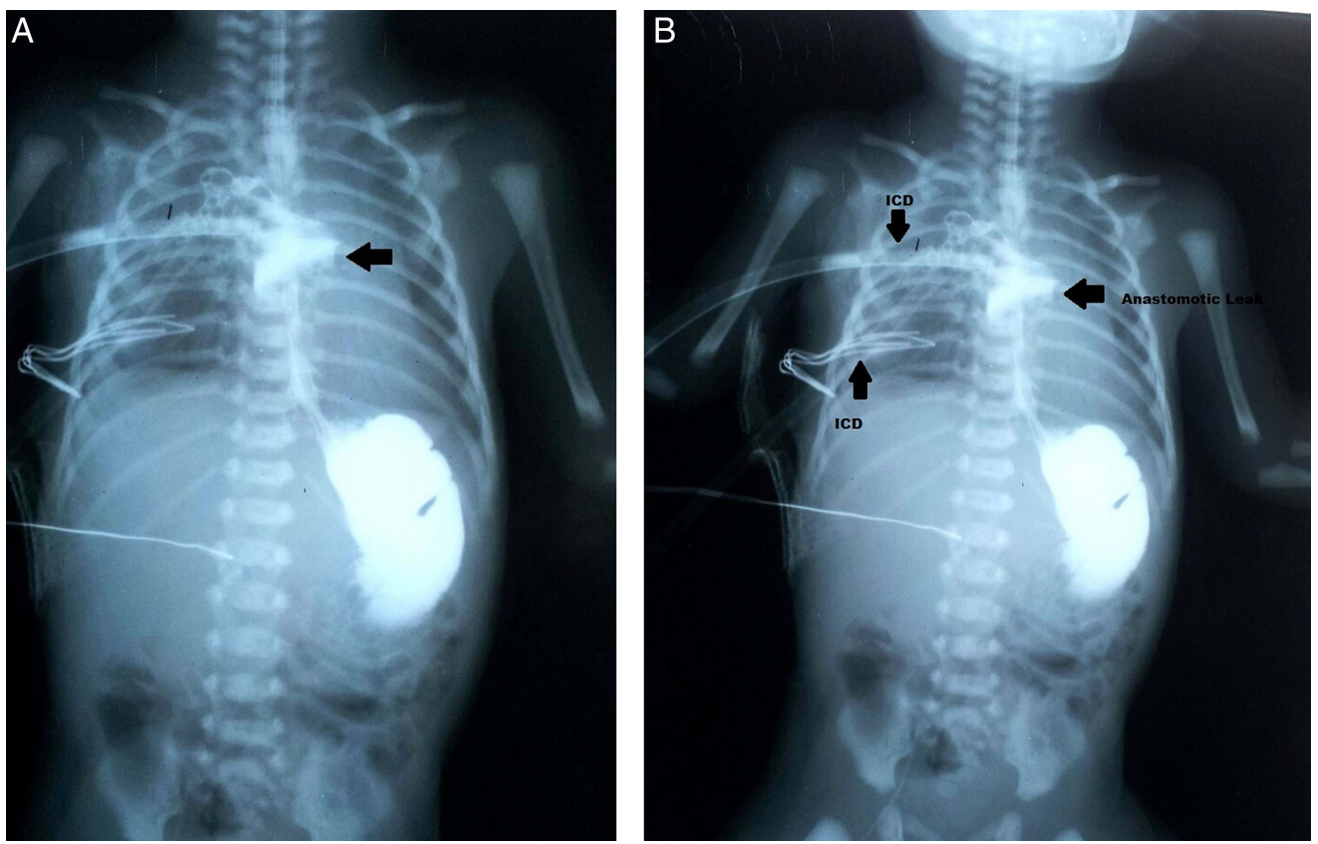

Figure 1 X-ray of the patient showing oesophagram performed. Note the anastomotic leak (A) present in the thoracic oesophagus, also note two right intercostal drainage tube inserted (B). 


\section{Learning points}

- Anastomotic leaks are seen in operated cases of tracheoesophageal fistula -operated cases which can be managed conservatively and rarely require a second operation.

- If a baby has worsening of respiratory distress postoperatively with an increase in respiratory distress, anastomotic leak must be strongly considered and managed.

- All the tracheoesophageal fistula-operated cases must be evaluated with esophagoram at end of first week for any anastomisis leak as missing the leak would be disastrous to the neonate.
Contributors DS wrote the manuscript and took images. TP critically analysed the manuscript and did corrections. SM did final corrections before submission.

Competing interests None.

Patient consent Obtained.

Provenance and peer review Not commissioned; externally peer reviewed.

\section{REFERENCES}

1 Mortell AE, Azizkhan RG. Esophageal atresia repair with thoracotomy: the Cincinnati contemporary experience. Semin Pediatr Surg 2009;18:12-19.

2 Manning PB, Morgan RA, Coran AG, et al. Fifty years' experience with esophageal atresia and tracheo-esophageal fistula. Beginning with Cameron Haight's first operation in 1935. Ann Surg 1986;204:446-53.

3 Tsai JY, Berkery L, Wesson DE, et al. Esophageal atresia and tracheo-esophageal fistula: surgical experience over two decades. Ann Thorac Surg 1997;64:778-83.

Copyright 2014 BMJ Publishing Group. All rights reserved. For permission to reuse any of this content visit http://group.bmj.com/group/rights-licensing/permissions.

BMJ Case Report Fellows may re-use this article for personal use and teaching without any further permission.

Become a Fellow of BMJ Case Reports today and you can:

- Submit as many cases as you like

- Enjoy fast sympathetic peer review and rapid publication of accepted articles

- Access all the published articles

- Re-use any of the published material for personal use and teaching without further permission

For information on Institutional Fellowships contact consortiasales@bmjgroup.com

Visit casereports.bmj.com for more articles like this and to become a Fellow 